\title{
Regulation of mitochondrial biogenesis during myogenesis
}

Citation for published version (APA):

Remels, A. H., Langen, R. C., Schrauwen, P., Schaart, G., Schols, A. M., \& Gosker, H. R. (2010).

Regulation of mitochondrial biogenesis during myogenesis. Molecular and Cellular Endocrinology, 315(1-

2), 113-120. https://doi.org/10.1016/j.mce.2009.09.029

Document status and date:

Published: 05/02/2010

DOI:

10.1016/j.mce.2009.09.029

Document Version:

Publisher's PDF, also known as Version of record

Document license:

Taverne

\section{Please check the document version of this publication:}

- A submitted manuscript is the version of the article upon submission and before peer-review. There can be important differences between the submitted version and the official published version of record.

People interested in the research are advised to contact the author for the final version of the publication, or visit the DOI to the publisher's website.

- The final author version and the galley proof are versions of the publication after peer review.

- The final published version features the final layout of the paper including the volume, issue and page numbers.

Link to publication

\footnotetext{
General rights rights.

- You may freely distribute the URL identifying the publication in the public portal. please follow below link for the End User Agreement:

www.umlib.nl/taverne-license

Take down policy

If you believe that this document breaches copyright please contact us at:

repository@maastrichtuniversity.nl

providing details and we will investigate your claim.
}

Copyright and moral rights for the publications made accessible in the public portal are retained by the authors and/or other copyright owners and it is a condition of accessing publications that users recognise and abide by the legal requirements associated with these

- Users may download and print one copy of any publication from the public portal for the purpose of private study or research.

- You may not further distribute the material or use it for any profit-making activity or commercial gain

If the publication is distributed under the terms of Article $25 \mathrm{fa}$ of the Dutch Copyright Act, indicated by the "Taverne" license above, 


\title{
Regulation of mitochondrial biogenesis during myogenesis
}

\author{
A.H.V. Remels ${ }^{a, *}$, R.C.J. Langen ${ }^{a}$, P. Schrauwen ${ }^{b}$, G. Schaart ${ }^{b}$, A.M.W.J. Schols ${ }^{\text {a }}$, H.R. Gosker ${ }^{a}$ \\ a Department of Respiratory Medicine, Maastricht University Medical Centre+, P.O. Box 5800, 6202 AZ Maastricht, The Netherlands \\ ${ }^{\mathrm{b}}$ Department of Human Biology, Maastricht University Medical Centre+, The Netherlands
}

\section{A R T I C L E I N F O}

\section{Article history:}

Received 27 April 2009

Received in revised form

27 September 2009

Accepted 28 September 2009

\section{Keywords:}

Peroxisome proliferator-activated

receptors

Myogenesis

Mitochondrial transcription factor A

Nuclear respiratory factor 1

Skeletal muscle

\begin{abstract}
A B S T R A C T
Pathways involved in mitochondrial biogenesis associated with myogenic differentiation are poorly defined. Therefore, $\mathrm{C}_{2} \mathrm{C}_{12}$ myoblasts were differentiated into multi-nucleated myotubes and parameters/regulators of mitochondrial biogenesis were investigated. Mitochondrial respiration, citrate synthase- and $\beta$-hydroxyacyl-CoA dehydrogenase activity as well as protein content of complexes I, II, III and $\mathrm{V}$ of the mitochondrial respiratory chain increased 4-8-fold during differentiation. Additionally, an increase in the ratio of myosin heavy chain $(\mathrm{MyHC})$ slow $v s$ MyHC fast protein content was observed. PPAR transcriptional activity and transcript levels of PPAR- $\alpha$, the PPAR co-activator PGC- $1 \alpha$, mitochondrial transcription factor $A$ and nuclear respiratory factor 1 increased during differentiation while expression levels of PPAR- $\gamma$ decreased. In conclusion, expression and activity levels of genes known for their regulatory role in skeletal muscle oxidative capabilities parallel the increase in oxidative parameters during the myogenic program. In particular, PGC- $1 \alpha$ and PPAR- $\alpha$ may be involved in the regulation of mitochondrial biogenesis during myogenesis.
\end{abstract}

(c) 2009 Elsevier Ireland Ltd. All rights reserved.

\section{Introduction}

Intrinsically, skeletal muscle is a tissue characterized by a high level of plasticity. The potential to alter muscle size, metabolic properties and/or protein isoform expression gives skeletal muscle the ability to adapt to the different challenges that may be placed upon it (Baldwin and Haddad, 2002). Events triggering skeletal muscle adaptive changes include endurance- and strength training, overload, aging, disuse, starvation, chronic illness and degenerative disorders (Fluck, 2006; Narici et al., 2004; Gosker et al., 2002). Growth and repair (regeneration) of skeletal muscle tissue are inextricably linked to the action of a group of myogenic precursor cells, called satellite cells. Upon activation, these cells proliferate, differentiate and ultimately fuse with existing myofibers (Anderson, 2006). The irreversible transition from the proliferation competent myoblast stage into fused multi-nucleated myotubes is known as myogenic differentiation and recapitulates developmental and regenerative myogenesis (Le Grand and Rudnicki, 2007).

Oxidative phenotype (OXPHEN) of a muscle depends on its oxidative capacity (determined by the activity of mitochondrial enzymes involved in oxidative substrate metabolism) and fiber type composition (e.g. ratio type I oxidative (slow-twitch) vs type IIB/X glycolytic (fast-twitch) fibers). The peroxisome proliferatoractivated receptors (PPARs), especially the PPAR- $\delta$ and PPAR- $\alpha$

\footnotetext{
* Corresponding author. Tel.: +31 43 3881563; fax: +31 433875051.

E-mail address: a.remels@pul.unimaas.nl (A.H.V. Remels).
}

isoforms, and related co-activator molecules as PGC- $1 \alpha$ are highly implicated in regulation of skeletal muscle OXPHEN (Luquet et al., 2003; Koves et al., 2005). Accordingly, muscle-specific overexpression of PPAR- $\delta$ or PGC- $1 \alpha$ in mice potently up-regulated oxidative capabilities of the muscle and mediated a fiber type shift towards an increased OXPHEN (Lin et al., 2002; Wang et al., 2004). Moreover, PGC- $1 \alpha$ and the PPARs govern mitochondrial biogenesis through control over other regulatory proteins including nuclear respiratory factor 1 (NRF-1) and the master mitochondrial regulator mitochondrial transcription factor A (Tfam) (Gleyzer et al., 2005; Wu et al., 1999). An improved muscle OXPHEN may be established during the process of myogenesis (i.e. the formation, repair or hypertrophy of muscle), or through alterations within the preexisting muscle fibers, independent of myogenic differentiation. The regulation of oxidative profile in existing muscle fibers has been described quite extensively in the literature (Lin et al., 2002; Wang et al., 2004; Canto et al., 2007) whereas knowledge regarding the development of muscle oxidative profile and the involvement of key regulators herein during myogenic differentiation is rather limited.

Studying the molecular events governing regulation of mitochondrial biogenesis during myogenesis is of clinical relevance for a number of pathological conditions including chronic inflammatory myopathies and degenerative muscle conditions as e.g. Duchenne's muscular dystrophy (Oexle and Kohlschutter, 2001; Wallace and McNally, 2009), but also in conditions characterized by loss of OXPHEN in skeletal muscle, such as COPD (Gosker et al., 2002). 
It has been shown that mitochondria play a mechanistic role not only in myoblast proliferation (Duguez et al., 2004; Rochard et al., 2000), but also in myogenesis by targeting key regulators of myogenic differentiation as myogenin (Rochard et al., 2000) and cellular oncogens as c-myc (Seyer et al., 2006). Moreover, blocking mitochondrial biogenesis potently inhibits myogenic differentiation (Herzberg et al., 1993; Rochard et al., 2000). This demonstrates that mitochondria display a retrograde signaling to regulate their own biogenesis as well as cell cycle progression (Jahnke et al., 2009), which subsequently implies that the investigation of myogenic differentiation is inevitably coupled to studying the process of mitochondrial biogenesis.

Although markers of OXPHEN (including mitochondrial biogenesis) during myogenesis have been described previously (Moyes et al., 1997; Rochard et al., 2000; Duguez et al., 2002, 2004; Kraft et al., 2006; Jahnke et al., 2009), information about the expression profile of key regulators during the entire myogenic program is incomplete. Therefore, the aim of the present study was to chart the development of multiple aspects of mitochondrial biogenesis during the full length of the differentiation process of skeletal muscle cells in order to increase our understanding of the key regulatory molecules of OXPHEN during myogenesis.

\section{Materials and methods}

\subsection{Cell culture}

The murine skeletal muscle cell line $C_{2} C_{12}$ was obtained from the American Type Culture Collection (ATCC CRL1772; Manassas, VA, USA). These cells are able to undergo differentiation into spontaneously contracting myotubes after growth factor withdrawal (Yaffe and Saxel, 1977). Myoblasts were cultured in growth medium (GM) composed of low-glucose Dulbecco's Modified Eagle's medium (DMEM) containing antibiotics ( $50 \mathrm{U} / \mathrm{ml}$ penicillin and $50 \mu \mathrm{g} / \mathrm{ml}$ streptomycin) and $9 \%(\mathrm{v} / \mathrm{v})$ foetal bovine serum (FBS) (all from GIBCO, Rockville, MD, USA). Cells were plated at $10^{4}$ cells $/ \mathrm{cm}^{2}$ and cultured in GM for $24 \mathrm{~h}$. To induce differentiation, cells were washed in Hank's Balanced Salt solution (HBSS) and GM was replaced with differentiation medium (DM), which contained DMEM with $0.5 \%$ heat-inactivated FBS and antibiotics. $\mathrm{C}_{2} \mathrm{C}_{12}$ cells were grown on Matrigel (BD Biosciences, Bedford, MA, USA) (1:50 in DMEM) (Becton Dickinson Labware, Bedford, MA, USA), which contains constituents of the natural extracellular matrix of skeletal muscle fibers including collagen IV, laminin, heparin sulfate proteoglycan and entactin.

\subsection{Transfections and plasmids}

For assessment of PPAR-dependent transcriptional activity, $\mathrm{C}_{2} \mathrm{C}_{12}$ cells were stably transfected with a PPAR-sensitive luciferase reporter plasmid containing 3 PPAR responsive elements in tandem derived from the promoter region of the acyl CoA oxidase (ACO) gene (pSG5, Stratagene, La Jolla, CA, USA). Cells were grown to $70 \%$ confluency and transfected by Lipofectamine according to manufacturer's instructions (Invitrogen, Carlsbad, CA, USA). Transfection was performed in the presence of $3.75 \mu \mathrm{g}$ ACO luciferase plasmid DNA (pSG5, Stratagene) and $0.25 \mu \mathrm{g}$ of a plasmid containing the neomycin resistance gene (pSV2-Neo, Stratagene). For selection of

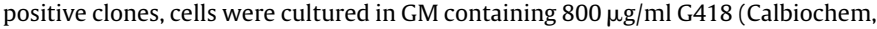
Nottingham, United Kingdom).

\subsection{May-Grunwald Giemsa staining}

As a morphological parameter of differentiation, the myogenic index was defined as the number of nuclei residing in cells containing three or more nuclei divided by the total number of nuclei in May-Grunwald Giemsa stained cells. Cells were grown on Matrigel-coated $60 \mathrm{~mm}$ dishes and differentiation was induced. After 0,3 or 7 days of differentiation cells were washed $2 \times$ in phosphate buffered saline (PBS) (room temperature), fixed in methanol and stained in May-Grunwald Giemsa (Sigma, St. Louis, MO, USA) according to manufacturer's instructions.

\subsection{Reporter assays}

The PPAR-sensitive reporter cell line was plated in $35 \mathrm{~mm}$ dishes and allowed to grow to $70 \%$ confluency. After induction of differentiation (day 0 ), cells were differentiated into myotubes for 3, 5 or 7 days after which cells were harvested. Cells were washed $2 \times$ with cold PBS and subsequently lysed by adding $(100 \mu \mathrm{l}) 1 \times$ Reporter Lysis Buffer (Promega, Madison, WI, USA) and incubation on ice for $10 \mathrm{~min}$. Cell lysates were centrifuged $(13,000 \times \mathrm{g}, 1 \mathrm{~min})$, and supernatants were snap-frozen and stored at $-80^{\circ} \mathrm{C}$ for later analysis. Luciferase activity was measured according to manufacturer's instructions (Promega) and corrected for total protein content (Biorad, Hercules, CA, USA).

\subsection{Real-time quantitative PCR (QPCR)}

Total RNA was extracted using the acid guanidium thiocyanate-phenolchloroform extraction method (Ambion Ltd., Ijssel, The Netherlands). RNA concentration was determined using a spectrophotometer. One microgram of RNA per sample was reverse-transcribed into cDNA according to the manufacturer's instructions (Reverse-i ${ }^{\mathrm{TM}} 1$ st strand synthesis, Abgene, Leusden, The Netherlands). cDNA was PCR-amplified with SYBR Green Fluorescein Mix (Westburg, Leusden, The Netherlands) on a Biorad PCR apparatus (Biorad). Specificity of the amplification was verified by melt curve analysis and evaluation of efficiency of PCR amplification. Primers were designed to generate a PCR amplification product of 100-150 bp (Table 1). Transcript levels for the constitutive housekeeping gene products cyclophilinA, hypoxanthine phosphoribosyltransferase (HPRT), $\beta$ actin and glyceraldehyde 3-phosphate dehydrogenase (GAPDH) were quantitatively measured in each sample to control for sample-to-sample differences in RNA concentration. Additionally, geNorm software was applied to calculate a normalization factor based on the expression levels of these 4 housekeepers. geNorm calculates the gene expression stability measure $M$ for a reference gene as well as the average pairwise variation $V$ for that gene with all other tested reference genes. Stepwise exclusion of the gene with the highest $M$-value allows ranking of the tested genes according to their expression stability. The underlying principles and calculations are described in Vandesompele et al. (2002). Gene expression was quantified and expressed as arbitrary units (AU).

\subsection{Western blotting}

Abundance of proteins involved in oxidative phosphorylation (OXPHOS) as well as myosin heavy chain $(\mathrm{MyHC})$ protein content was evaluated by Western blotting. Cells were washed in PBS and whole cell lysates were prepared by the addition of lysis buffer ( $20 \mathrm{mM}$ Tris, $150 \mathrm{mM} \mathrm{NaCl}, 1 \%$ (v/v) Nonidet P-40, $1 \mathrm{mM}$ DTT, $1 \mathrm{mM}$ $\mathrm{Na}_{3} \mathrm{VO}_{4}, 1 \mathrm{mM}$ PMSF, $10 \mu \mathrm{g} / \mathrm{ml}$ leupeptin, and $1 \%(\mathrm{v} / \mathrm{v}$ ) aprotenin). Lysates were incubated on ice for $30 \mathrm{~min}$, followed by $30 \mathrm{~min}$ of centrifugation at $13,000 \times \mathrm{g}$. A fraction of the supernatant was saved for protein determination and $4 \times$ Laemmli sample buffer (0.25 M Tris-HCl; pH 6.8, 8\% (w/v) SDS, 40\% (v/v) glycerol, $0.4 \mathrm{M}$ DTT, and $0.04 \%(\mathrm{w} / \mathrm{v})$ bromophenol blue) was added, followed by boiling of the samples for $5 \mathrm{~min}$ and storage at $-20^{\circ} \mathrm{C}$. Total protein was assessed using the Biorad DC protein assay kit (Biorad) according to the manufacturer's instructions. $25 \mu \mathrm{g}$ or $2 \mu \mathrm{g}$ of protein (OXPHOS and MyHC respectively) was loaded per lane and separated on a $10 \%$ polyacrylamide gel (Mini Protean 3 system; Biorad), followed by transfer to a $0.45 \mu \mathrm{m}$ nitrocellulose membrane (Biorad) by electroblotting. The membrane was blocked for $1 \mathrm{~h}$ at room temperature in $5 \%(\mathrm{w} / \mathrm{v})$ non-fat dry milk. Nitrocellulose blots were washed in PBS-Tween 20 (0.05\%), followed by overnight incubation $\left(4{ }^{\circ} \mathrm{C}\right)$ with a polyclonal antibody specific for OXPHOS proteins (Cell Signaling, Beverly, MA, USA) or MyHC fast or slow (Sigma). After three wash steps of $20 \mathrm{~min}$ each, the blots were probed with a peroxidase-conjugated secondary antibody (Vector Laboratories, Burlingame, CA, USA) and visualized using SuperSignal West Pico chemiluminescent substrate (Pierce Biotechnology, Rockford, IL, USA) according to the manufacturer's instructions.

\subsection{Enzyme activity assay}

Cells were washed twice in ice-cold PBS and subsequently lysed by $10 \mathrm{~min}$ incubation with $200 \mu$ l of $0.1 \%$ Triton-X100 dissolved in PBS. Cells were harvested by scraping, using rubber policemen, and transferred to an Eppendorf tube containing $45 \mu \mathrm{l} 5 \%$ bovine serum albumine (BSA). After vortexing for $10 \mathrm{~s}$, samples were centrifuged $\left(10 \mathrm{~min}, 13,000 \times \mathrm{g}, 4^{\circ} \mathrm{C}\right)$, and the supernatant was used for spectrophotometrical assessment of the following enzyme activities: HAD, EC 1.1.1.35 (see Gosker et al., 2005); CS, EC 2.3.3.1 (see Gosker et al., 2005); and CK, EC 2.7.3.2 (see Langen et al., 2003) (Multiskan Spectrum; Thermo Labsystems, Breda, The Netherlands). Enzyme activities were corrected for total protein content (Biorad).

\subsection{Mitochondrial respiration}

$\mathrm{C}_{2} \mathrm{C}_{12}$ myoblasts or differentiated myotubes were harvested in trypsin, washed twice with MIRO5 respiration medium $\left(37^{\circ} \mathrm{C}\right)$ (prepared according to MiPNet protocols) (Oroboros Instruments, Innsbruck, Austria) and, after a 5 min centrifugation at $500 \times \mathrm{g}$, resuspended in $2.0 \mathrm{ml}$ of MIRO5 respiration medium. Protein content was determined in dishes that were cultured in a parallel experiment. Measurement of respiration was performed by a polarographic oxygen sensor in a $2 \mathrm{ml}$ glass chamber of the respirometer Oxygraph $2 \mathrm{~K}$ (Oroboros Instruments). The amplified signal from the oxygen sensor was recorded on a computer at sampling intervals of $2 \mathrm{~s}$ using DatLab acquisition software (Oroboros Instruments). The respiration medium was equilibrated with air at $37^{\circ} \mathrm{C}$ and stirred until a stable signal was obtained for calibration at air saturation. After calibration the medium was replaced by aerated cell suspensions at a volume of $2.0 \mathrm{ml}$. After insertion, cells were permeabilized using $1 \mu \mathrm{l}$ of digitonin $(0.5 \mu \mathrm{g} / \mathrm{ml}$ final concentration $)$ and substrates were added in chronological order (volume; final concentration): malate ( $5 \mu \mathrm{l} ; 2 \mathrm{mM})$, followed by 
Table 1

Primer details.

\begin{tabular}{|c|c|c|}
\hline \multirow[t]{2}{*}{ Primer } & \multicolumn{2}{|l|}{ QPCR primer sequences } \\
\hline & Forward $5^{\prime}-3^{\prime}$ & Reverse $5^{\prime}-3^{\prime}$ \\
\hline PPAR- $\alpha$ & AGTGCCCTGAACATCGAGTGT & AAGCCCTTACAGCCTTCACATG \\
\hline PPAR- $\delta$ & GAGCAAGTGGCCACGGGTGAC & CCACCTGAGGCCCATCACAG \\
\hline PPAR- $\gamma$ & TGGGGATGTCTCACAATGCCA & TTCCTGTCAAGATCGCCCTCG \\
\hline PGC $-1 \alpha$ & AAACCACACCCACAG GATCAG & TCTTCGCTTTATTGCTCCATGA \\
\hline Tfam & CGGAGTTCCCACGCTGG & CCGTCCGGTTCGTCTCAC \\
\hline NRF-1 & CСТCСAAACCTGCATCTCAC & TCGCACCACATTCTCCAAAG \\
\hline COXVa & TGCGAGCATGTAGACGGTTAAAT & GAGGTCCTGCTTTGTCCTTAACA \\
\hline COXVIIc & GGCCAGAGTATCCGGAGGTT & CCACTGAAAATGGCAAATTCTTC \\
\hline COXII & CCATCCCAGCCCGACTAA & ATTTCAGAGCATTGGCCATAGAA \\
\hline COXIII & GGTCTCGGAAGTATTTTTCTTTGC & CAGCAGCCTCCTAGATCATGTG \\
\hline CyclophilinA & TTССТССТTTСAСAGAATTATTCСA & CCGCCAGTGCCATTATGG \\
\hline GAPDH & CAACTCACTCAAGATTGTCAGCAA & TGGCAGTGATGGCATGGA \\
\hline HPRT & TGGATATGCCCTTGACTATAATGAGTAC & AGGACTCCTCGTATTTGCAGATTC \\
\hline$\beta$-Actin & CTGAATGGCCCAGGTCTGA & CCCTCCCAGGGAGACCAA \\
\hline
\end{tabular}

Peroxisome proliferator-activated receptor: PPAR; PPAR- $\gamma$ co-activator 1 alpha: PGC- $1 \alpha$; mitochondrial transcription factor A: Tfam; nuclear respiratory factor 1: NRF-1; cytochrome $c$ oxidase: COX; glyceraldehyde 3-phosphate dehydrogenase: GAPDH; hypoxanthine phosphoribosyltransferase: HPRT.

glutamate $(10 \mu \mathrm{l} ; 10 \mathrm{mM})$ or pyruvate $(5 \mu \mathrm{l} ; 5 \mathrm{mM})$ or palmitoyl-carnitine $(10 \mu \mathrm{l}$; $50 \mu \mathrm{M})$ followed by ADP $(20 \mu \mathrm{l} ; 5 \mathrm{mM})$. At the end of the substrate trace a titration with the uncoupling agent FCCP was performed ( $1 \mu \mathrm{l} ; 0.5 \mu \mathrm{M}$ titration). Oxygen consumption ( $\mathrm{pmol} / \mathrm{mls}$ ) was calculated as a negative time derivative of oxygen concentration $(\mathrm{nmol} / \mathrm{ml})$. Respiration rates were corrected for total protein content to correct for variability in cellular input.

\subsection{Mitochondrial DNA copy number}

Mitochondrial DNA (mtDNA) copy number was determined as a marker for mitochondrial density using QPCR. Total DNA was isolated from the cells according to manufacturer's instructions (Nucleospin, Machery Nagel, Ede, The Netherlands). A serial dilution standard curve was prepared from a pool of all the samples. Realtime PCR was carried out at the following parameters: 15 min denaturation step at $95^{\circ} \mathrm{C}$, followed by 40 cycles at $95^{\circ} \mathrm{C}$ for $15 \mathrm{~s}$ and $60^{\circ} \mathrm{C}$ for $45 \mathrm{~s}, 30 \mathrm{~s}$ at $95^{\circ} \mathrm{C}$ and $30 \mathrm{~s}$ at $60^{\circ} \mathrm{C}$ followed by a stepwise increase of $0.5^{\circ} \mathrm{C}$ until $95^{\circ} \mathrm{C}$ was reached (melt curve analysis). Mitochondrial DNA copy number was calculated from the ratio COXII/cyclophilinA or COXIII/cyclophilinA.

\subsection{Statistical analysis}

Data was analyzed according to the guidelines of Altman et al. using SPSS (Statistical Package for the Social Sciences, SPSS Inc., Chicago, IL, USA) (Altman et al., 1983). Kruskal-Wallis tests were applied for mean comparisons as a function of time and non-parametric tests were used to detect significant differences between individual time points. Data is represented as the mean $\pm \mathrm{SD}$. A two-tailed probability value of less than 0.05 was considered to be significant.

\section{Results}

\subsection{Markers of myogenic differentiation}

In order to characterize myogenic differentiation of $\mathrm{C}_{2} \mathrm{C}_{12}$ cells we compared biochemical and structural markers of differentiation in myoblasts $v s$ differentiating/differentiated myotubes. Results are summarized in Table 2 and are illustrative of good morphological and biochemical differentiation.

Table 2

Parameters of myogenic differentiation.

\begin{tabular}{llcc}
\hline & Myoblasts & Myotubes (day 3) & Myotubes (day 7) \\
\hline MyHC fast (AU) & 0 & $1.7 \pm 0.4^{*}$ & $3.9 \pm 0.6^{*}$ \\
CK (U/mg protein) & $0.010 \pm 0.003$ & $0.081 \pm 0.023^{*}$ & $0.734 \pm 0.087^{*}$ \\
Myogenic index & 0 & $0.22 \pm 0.04^{*}$ & $0.51 \pm 0.08^{*}$ \\
\hline
\end{tabular}

Values are expressed as mean \pm SD from 3 independent experiments. MyHC: myosin heavy chain; CK: creatine kinase; myogenic index: the number of nuclei residing in cells containing three or more nuclei divided by the total number of nuclei in May-Grunwald Giemsa stained cells.

$p<0.001$ (significance of difference compared to myoblasts).

\subsection{Mitochondrial respiration in myoblasts and myotubes}

To investigate the development of oxidative capacity during $\mathrm{C}_{2} \mathrm{C}_{12}$ myogenesis, we measured mitochondrial $\mathrm{O}_{2}$ consumption in proliferating $\mathrm{C}_{2} \mathrm{C}_{12}$ myoblasts and differentiated myotubes (differentiated 7 days) in response to different substrates. As depicted in Fig. 1, basal respiratory rate was higher in myotubes when compared to myoblasts in the presence of endogenous substrates (basal respiration) $(p=0.050)$. FCCP-induced respiration (maximal respiration), bypassing respiratory control by ATPase and thus reflecting maximal respiratory capacity, was 4-fold higher in myotubes compared to myoblasts $(p=0.050)$. Shown in Fig. 1 is the maximal respiratory capacity with palmitoyl-carnitine as a substrate. Differences in maximal respiratory capacity between myoblasts and myotubes were similar when other substrates were used (glutamate and pyruvate respectively, data not shown).

\subsection{Mitochondrial markers during myogenesis}

To gain insight in mitochondrial functioning and mitochondrial biogenesis during differentiation of $\mathrm{C}_{2} \mathrm{C}_{12}$ cells into mature myotubes, we measured several mitochondrial markers. These

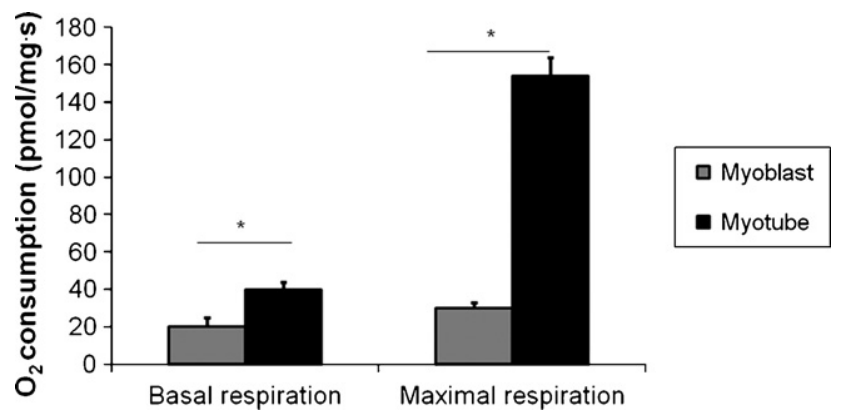

Fig. 1. Mitochondrial respiration in $C_{2} C_{12}$ myoblasts $v s$ differentiated myotubes. Mitochondrial respiration was measured in proliferating myoblasts and in myotubes which were differentiated for 7 days in DM. Cells were harvested and oxygen consumption was measured. Basal respiration (on endogenous substrates) was determined after adding the cells to the chambers. After permeabilization with digitonin $(1 \mu \mathrm{l} ; 0.5 \mu \mathrm{g} / \mathrm{ml})$, the following substrates were added to the cells: malate $(5 \mu \mathrm{l} ; 2 \mathrm{mM})$, glutamate $(10 \mu \mathrm{l} ; 10 \mathrm{mM})$ or pyruvate $(5 \mu \mathrm{l} ; 5 \mathrm{mM})$ or palmitoyl-carnitine $(10 \mu \mathrm{l} ; 50 \mu \mathrm{M})$ followed by ADP $(20 \mu \mathrm{l} ; 5 \mathrm{mM})$ and oligomycin $(1 \mu \mathrm{l} ; 1.66 \mu \mathrm{g} / \mathrm{ml})$. Maximal respiration was determined after titration with FCCP ( $1 \mu \mathrm{l} ; 0.5 \mu \mathrm{M}$ titration). Respiration rates were corrected for total protein content. Data is represented as mean \pm SD for 3 independent experiments. Oxygen consumption is given in $\mathrm{pmol} /(\mathrm{mg} \mathrm{s})$. Significance of difference: ${ }^{*} p \leq 0.050$. 

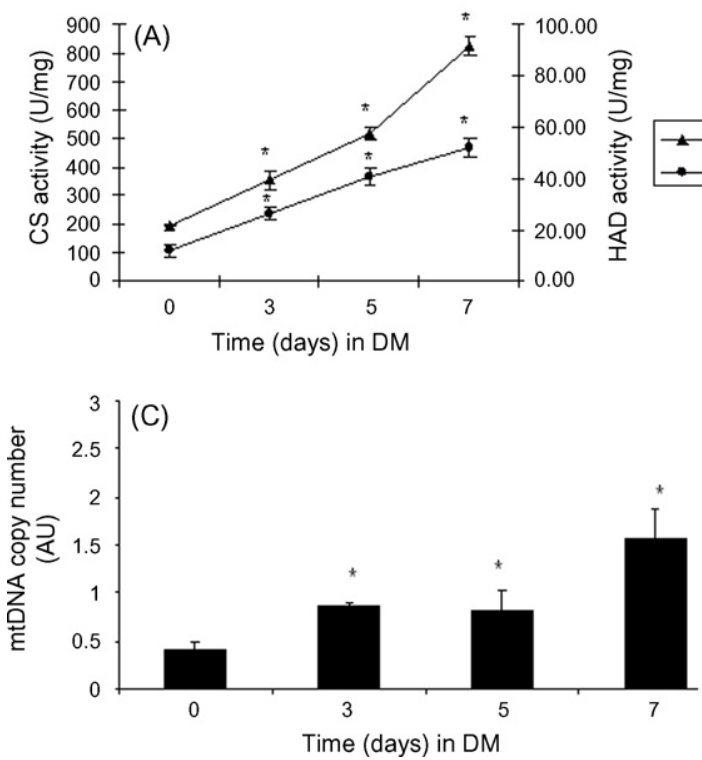
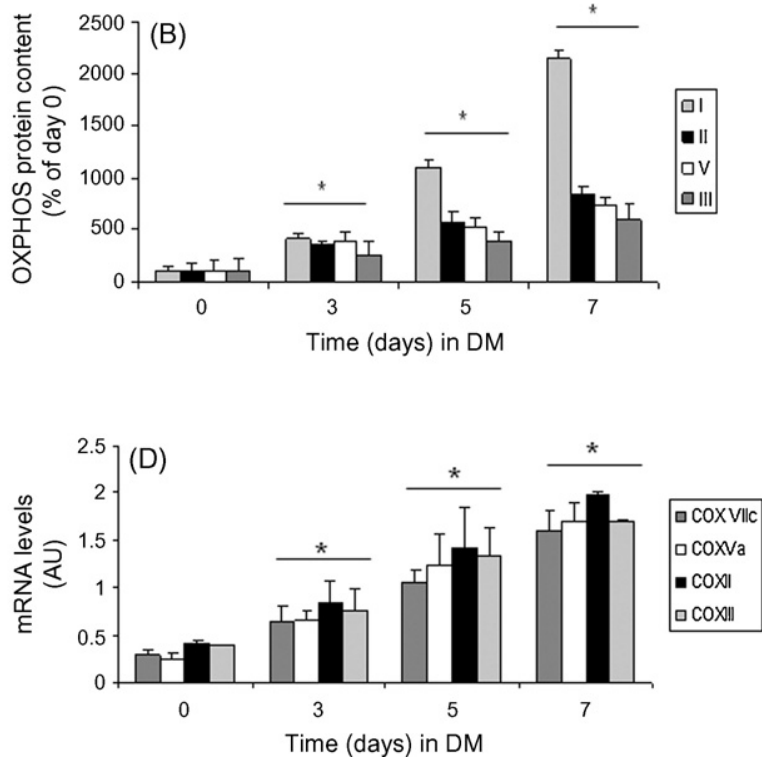

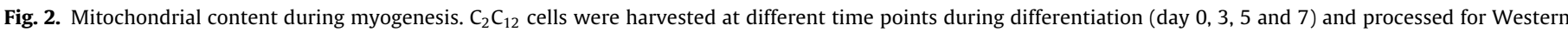

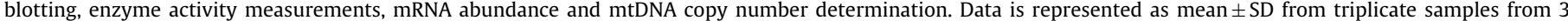

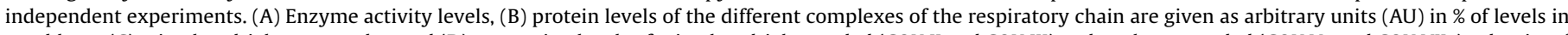

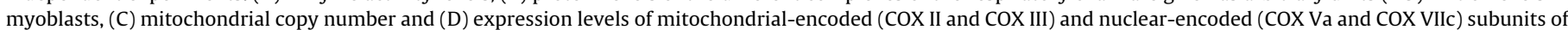
COX are expressed as arbitrary units (AU) after correction for the housekeeping gene cyclophilinA. Significance of difference compared to myoblasts (day 0 ): * $p \leq 0.050$.

included activity levels of enzymes involved in substrate oxidation, to assess functionality of the citric acid cycle and fatty acid $\beta$-oxidation pathway, structural components of the respiratory chain (OXPHOS) and mtDNA copy number as a general marker for mitochondrial content. Additionally, we also investigated mRNA transcript levels of cytochrome $c$ oxidase (COX) subunits II and III (mitochondrial-encoded) and subunits Va and VIIc (nuclear-encoded). Activity levels of enzymes involved in oxidative metabolism, CS (Krebs cycle) and HAD ( $\beta$-oxidation), increased approximately 4-fold during myogenesis $(p=0.016)$ (Fig. 2A). Accordingly, protein levels of all investigated complexes of the respiratory chain increased up to 8 -fold $(p=0.019,0.023$, 0.021 and 0.016 for complex I, II, III and V respectively) (Fig. 2B) while mtDNA copy number was 4 -fold higher in fully differentiated myotubes compared to myoblasts $(p=0.025)$ (Fig. 2C). As illustrated in Fig. 2D, transcript levels of the mitochondrial-encoded subunits COX II and COX III as well as the nuclear-encoded subunits Va and VIIc increased during differentiation $(p=0.023$ and 0.026 respectively).

\subsection{Myosin heavy chain isoform protein content during myogenesis}

To assess the distribution of MyHC isoforms during myogenesis, we investigated protein levels of MyHC fast (type II) and MyHC slow (type I) isoforms in $\mathrm{C}_{2} \mathrm{C}_{12}$ cells. MyHC protein levels are expressed as the ratio between the slow and fast isoform. Myoblasts expressed extremely low levels of both MyHC fast and slow isoforms whereas differentiated myotubes expressed significant amounts of both isoforms. During differentiation a relative higher increase in MyHC slow isoform was observed compared to MyHC fast isoform expres$\operatorname{sion}(p=0.025)$ (Fig. 3).

\subsection{PPARs and related factors during differentiation}

We determined mRNA transcript levels of PGC- $1 \alpha$ and all PPAR isotypes at different time points during the differentiation process. As illustrated in Fig. 4, PGC- $1 \alpha$ and PPAR- $\alpha$ mRNA expression levels increased ( $p=0.063$ and 0.024 respectively) while PPAR- $\gamma$ showed decreased mRNA expression levels during differentiation $(p=0.016)$. PPAR- $\delta$ mRNA expression levels were stable during the full myogenic program. Data was corrected for a normalization factor derived from a geNorm analysis of 4 housekeepers (cyclophilinA, $\beta$-actin, GAPDH and HPRT). The average expression stability ( $M$-value) for cyclophilinA, $\beta$-actin, GAPDH and HPRT was $0.473,0.987,0.688$ and 0.470 respectively. Pairwise comparison for inclusion of a fourth housekeeping gene (V3/4) was 0.244 indicating preferable use of 4 housekeeping genes. It must be mentioned that expression levels of all 4 investigated housekeeping genes decreased approximately 2-fold during differentiation of $\mathrm{C}_{2} \mathrm{C}_{12}$ cells (data not shown). However, similar patterns of expression of all genes of interest were observed when data was corrected for any of the 4 individual housekeepers or when correction based on the geNorm normalization factor was applied. In addition to the PPARs and their co-activator PGC- $1 \alpha$, mRNA levels of 2 key regulators of mitochondrial biogenesis downstream of PGC- $1 \alpha$ (NRF-1

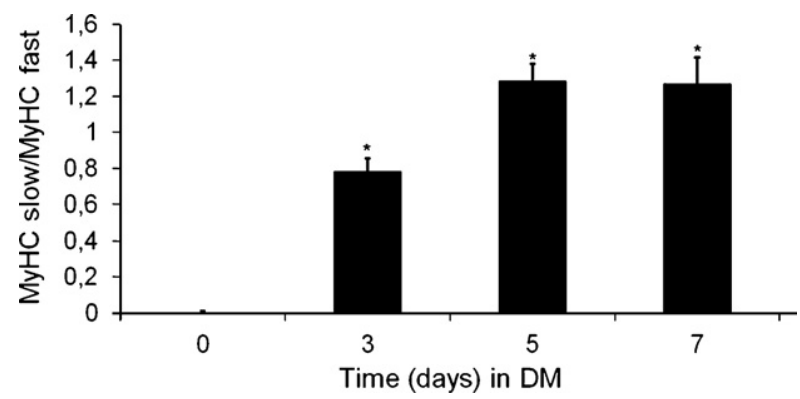

Fig. 3. Myosin heavy chain (MyHC) distribution in $\mathrm{C}_{2} \mathrm{C}_{12}$ cells during differentiation $\mathrm{C}_{2} \mathrm{C}_{12}$ cells were harvested at different time points during differentiation (day 0,3 , 5 and 7) and MyHC isoform protein levels were quantified by Western blot analysis. Protein levels of MyHC isoforms were corrected for total protein content. Data is represented as mean \pm SD from triplicate samples from 3 independent experiments. Protein levels are given as arbitrary units (AU). Quantified MyHC protein levels are expressed as the ratio between the slow and fast isoform. Significance of difference compared to myoblasts (day 0 ): ${ }^{*} p \leq 0.050$. 

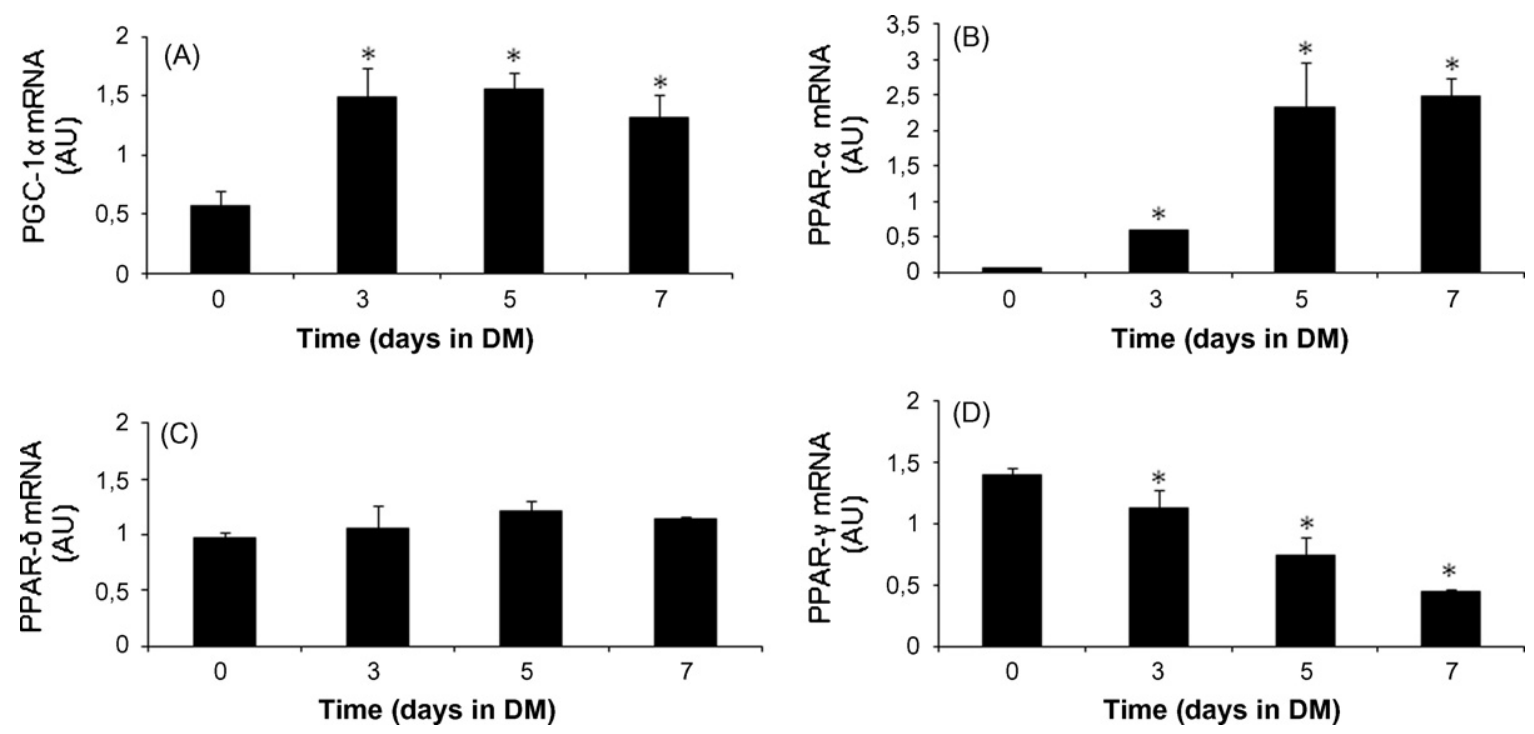

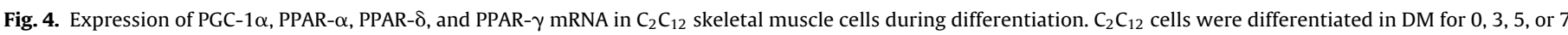

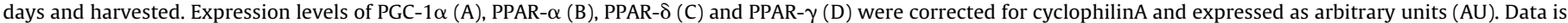

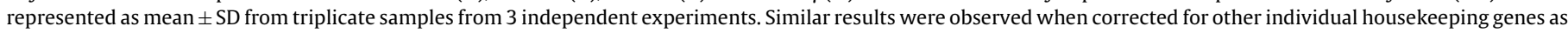

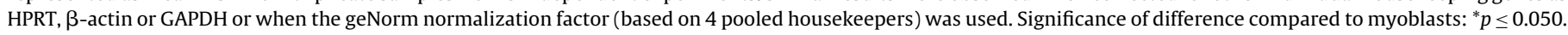
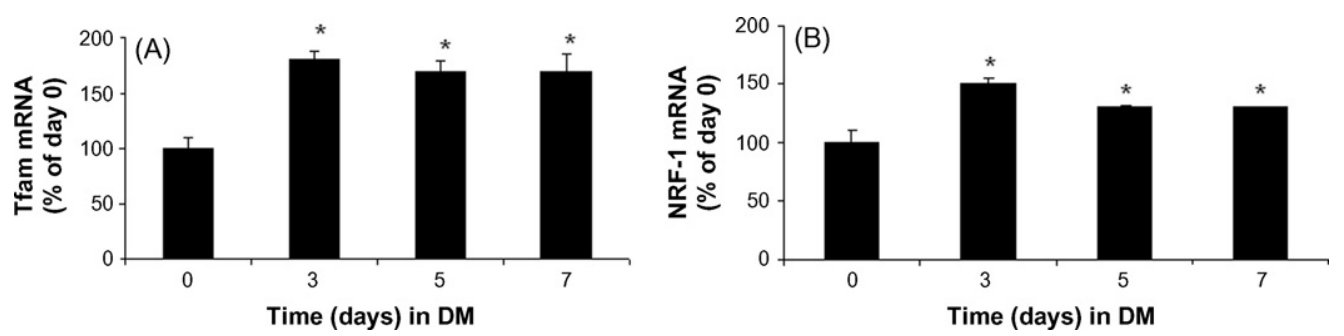

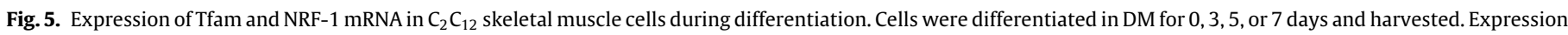

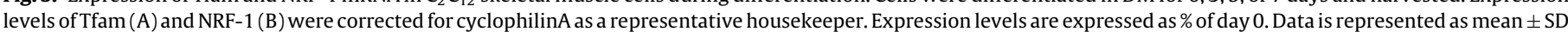

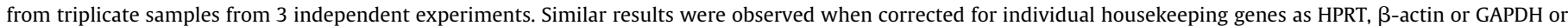
when the geNorm normalization factor based on 4 different housekeepers was used. Significance of difference compared to myoblasts: ${ }^{*} p \leq 0.050$.

and Tfam), were also determined during the myogenic program of $\mathrm{C}_{2} \mathrm{C}_{12}$ cells. Tfam and NRF-1 mRNA expression levels increased from day 0 until day 3 of the differentiation process and remained increased for the duration of the differentiation process $(p=0.096$ and 0.024 respectively) (Fig. 5). Data corrected for the housekeeper cyclophilinA is shown as a representative housekeeper, but similar results were obtained with all other individual housekeeping genes as well as with the geNorm normalization factor.

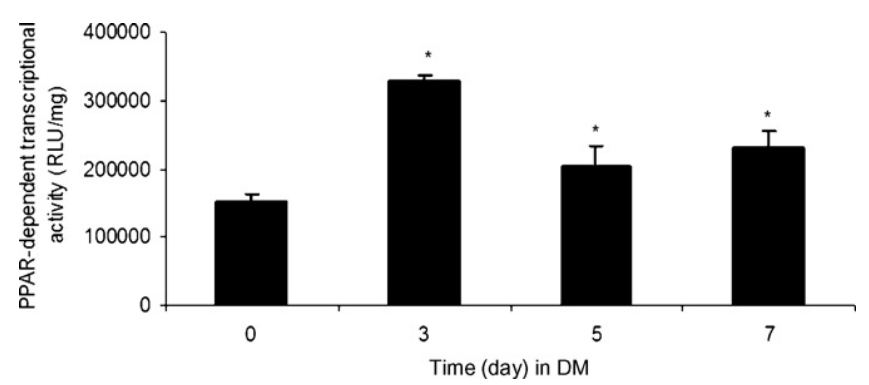

Fig. 6. PPAR-dependent transcriptional activity in $C_{2} C_{12}$ skeletal muscle cells during differentiation. $C_{2} C_{12}$ cells stably containing a PPAR-sensitive reporter construct were differentiated in DM for $0,3,5$, or 7 days and harvested. Cells were lysed; luciferase activity was determined and normalized to total protein content. Significance of difference compared to myoblasts: ${ }^{*} p \leq 0.050$. Error bars indicate the SD. Shown are the mean \pm SD of 3 independent experiments.

\subsection{PPAR-dependent transcriptional activity}

The PPARs as well as PGC- $1 \alpha$ are highly implicated in the regulation of skeletal muscle oxidative capacity (Lin et al., 2002; Wang et al., 2004; Canto et al., 2007). Therefore, we investigated PPARdependent transcriptional activity during differentiation of $\mathrm{C}_{2} \mathrm{C}_{12}$ cells into multi-nucleated myotubes. As depicted in Fig. 6, PPARdependent transcriptional activity increased during differentiation $(p=0.022)$.

\section{Discussion}

In the present paper we show that multiple key determinants of OXPHEN develop during myogenic differentiation, which coincides with the initiation of mitochondrial biogenesis and increased expression-and activity levels of key regulators of muscle OXPHEN.

\subsection{Constituents of OXPHEN}

During the process of myogenic differentiation a remarkable morphological transition from myoblasts into multi-nucleated myotubes is observed. In addition, myogenesis is accompanied by an increase in oxidative metabolism as we demonstrate in a detailed manner in the present study. We show an increased mitochondrial respiratory capacity, as well as increased protein content of the complexes of the inner mitochondrial membrane respiratory 
chain, which is the site of $\mathrm{O}_{2}$ consumption (Mathieu-Costello and Hepple, 2002). In addition, we observed increased enzyme activity levels of HAD and CS and more oxidative type I MyHC slow protein in myotubes as compared to myoblasts. This is in concordance with previous studies and is illustrative of development of OXPHEN during myogenesis (Duguez et al., 2002; Leary et al., 1998). The observed increase in the activity level of CS (established marker of mitochondrial volume) as well as increased mtDNA copy number and increases in different COX mRNA levels confirm increased mitochondrial biogenesis (Kim et al., 1995). This data collectively shows that myogenic differentiation of $\mathrm{C}_{2} \mathrm{C}_{12}$ cells is obviously associated with mitochondrial biogenesis. It can however not be excluded that, in addition to mitochondrial biogenesis, alterations in efficiency of mitochondria contribute to an increased mitochondrial capacity during myogenesis.

\subsection{Regulators of OXPHEN}

Coordination of the nuclear-and mitochondrial genome during mitochondrial biogenesis is regulated by a network of transcription factors including PGC- $1 \alpha$, PPARs, NRF- 1 and Tfam (Butow and Bahassi, 1999). In this signaling pathway, PGC- $1 \alpha$ is the master regulator coordinating PPAR activity levels as well as mitochondrial biogenesis through activation of NRF-1-mediated transcription of Tfam (Baar, 2004; Scarpulla, 2002). In the present study, PGC-1 $\alpha$ expression increased during myogenesis. The role of PGC- $1 \alpha$ in positive regulation of oxidative capacity and fiber type composition of existing muscle is well established (Lin et al., 2002). Our data now also suggests a role for PGC- $1 \alpha$ in the development of OXPHEN during myogenic differentiation. In line with this notion, PGC- $1 \alpha$ mRNA levels increased during mitochondrial biogenesis in a mouse model of skeletal muscle regeneration, although these authors did not demonstrate that the induction of PGC- $1 \alpha$ expression was associated with myogenic differentiation or took place in pre-existing muscle fibers (Duguez et al., 2002).

The PPARs are known to be strongly involved in the control of genes encoding enzymes of the fatty acid oxidation pathway as e.g. HAD (Wang et al., 2003). In concordance, we observed a clear induction of PPAR transcriptional activity and HAD activity during the initiation of myogenic differentiation. To the best of our knowledge, this is the first study investigating PPAR transcriptional activity during skeletal muscle cell differentiation. Typically, PPAR- $\alpha$ and PPAR- $\delta$ are the 2 isoforms most implicated in positive regulation of fatty acid oxidative capacity of skeletal muscle, whereas PPAR- $\gamma$ is the isoform implicated in fatty acid uptake and storage (Singh et al., 2007; Fredenrich and Grimaldi, 2004; Lefebvre et al., 2006). Therefore, it is conceivable that the increase in PPAR transcriptional activity is mainly due to increased PPAR- $\alpha$ and/or PPAR- $\delta$ transcriptional activity.

In concordance with this suggestion, we found that PPAR- $\gamma$ mRNA levels markedly decreased during differentiation. It has been shown that constitutive high expression levels of PPAR- $\gamma$ in skeletal muscle cells can result in trans-differentiation into adipocytes $\mathrm{Hu}$ et al., 1995). On the other hand, low critical levels of PPAR- $\gamma$ expression are required to maintain the ability to differentiate properly (Singh et al., 2007). Since $C_{2} C_{12}$ cell metabolism during differentiation is directed towards a more OXPHEN and PPAR- $\gamma$ is implicated in storage of fatty acids, reduction of PPAR- $\gamma$ expression may be a regulatory mechanism to ensure an adequate development of the oxidative capacity of the cell. In contrast to PPAR- $\gamma$, PPAR- $\alpha$ expression levels increased dramatically in our study. PPAR- $\delta$ mRNA levels on the other hand remained constant during the entire differentiation process despite its clearly established role in regulation and development of skeletal muscle oxidative capacity (Luquet et al., $2003,2005)$. Kraft et al. previously showed a 10 -fold increase in PPAR- $\alpha$ expression levels in differentiating $C_{2} C_{12}$ cells, although they only investigated the myogenic program up to 3 days of differentiation (Kraft et al., 2006). We now show that, in line with enzyme activity data, PPAR- $\alpha$ mRNA expression levels increase until day 5 of differentiation reaching a 40 -fold higher level in myotubes compared to myoblasts. To date, no other studies have previously investigated PPAR- $\delta$ expression levels during skeletal muscle differentiation.

The increase in expression levels of PGC- $1 \alpha$ and PPAR- $\alpha$ during differentiation parallels the observed increase in markers of OXPHEN. In addition to their well established role as positive regulators of oxidative capacity of existing muscle fibers (Lin et al., 2002; Wang et al., 2004; Canto et al., 2007), this therefore also suggests a role for these regulators in the development of oxidative capacity during myogenesis. Although whole-body knockout PGC- $1 \alpha$ animals only display a $20-30 \%$ reduction in mitochondrial content (Leick et al., 2008, 2009), muscle-specific over-expression of PGC$1 \alpha$ does result in an increase in basal OXPHEN (Lin et al., 2002). This implies that PGC- $1 \alpha$ is a potent stimulator of mitochondrial biogenesis but may not always be required. Possibly, other co-factors in the PGC- $1 \alpha$ family as PRC and PGC- $1 \beta$ compensate for the loss of PGC $-1 \alpha$ in the PGC $-1 \alpha$ knockouts (Scarpulla, 2008; Ishii et al., 2009). It must also be noted that the PGC- $1 \alpha$ knockout mouse is characterized by physical hyperactivity which may cause exerciseinduced mitochondrial biogenesis and potentially obscures any loss of baseline mitochondrial biogenesis (Lin et al., 2004). In addition to PGC- $1 \alpha$, our data also suggests a role for PPAR- $\alpha$ in mitochondrial biogenesis. It has been demonstrated that PPAR- $\alpha$ knockout mice display reduced activity levels of fatty acid oxidation enzymes as HAD, however no loss of other mitochondrial enzymes was observed (Bedu et al., 2007). Future studies are therefore needed to address the requirement and the exact role of PPAR- $\alpha$ in skeletal muscle mitochondrial biogenesis. In contrast to PGC- $1 \alpha$ and PPAR$\alpha$, our data suggests that differential expression levels of PPAR- $\delta$ are not implicated in the process of mitochondrial biogenesis during myogenic differentiation. This is in line with a recent paper from Kleiner et al. who demonstrated that PPAR- $\delta$ agonism activates fatty acid oxidation, which is confirmed in mice with skeletal muscle-specific PPAR- $\delta$ over-expression (Luquet et al., 2003), but fails to induce mitochondrial gene expression and function (Kleiner et al., 2009). It can be speculated that PPAR- $\delta$ activation directs the metabolic profile of existing fibers towards a more developed OXPHEN while PGC- $1 \alpha$-mediated PPAR- $\alpha$ activation may regulate development of oxidative capacity in new muscle fibers during myogenesis. Nevertheless, as PPAR- $\delta$ remains a specific regulator of fatty acid oxidation, which is part of the mitochondrial machinery, it still contributes to muscle OXPHEN. In line with a positive role in determining skeletal muscle OXPHEN, increased PGC- $1 \alpha$ and PPAR- $\alpha$ mRNA expression levels during differentiation may mediate the observed increase in transcription of nuclear-encoded constituents of the mitochondrial respiratory chain. Next to being a co-activator for PPARs, PGC- $1 \alpha$ also functions as a co-activator for NRF-1. Subsequently, PGC- $1 \alpha / N R F-1$ induces the expression of Tfam which is the master regulator of mitochondrial biogenesis (Gleyzer et al., 2005). In the present study, Tfam and NRF-1 expression levels increased at the onset of differentiation, which is in line with the start of mitochondrial biogenesis in these cells at the beginning of the myogenic program. Since Tfam is a master regulator of the transcription and replication of mtDNA (Gleyzer et al., 2005), its observed up-regulation likely mediated the increased mtDNA content during $\mathrm{C}_{2} \mathrm{C}_{12}$ myogenic differentiation. Additionally, we observed increased mRNA levels of mitochondrial-encoded COX subunits which may also result from increased transcription of the mitochondrial genome by Tfam.

In conclusion, in the present paper we describe temporal profiles of a number of key constituents of OXPHEN and mitochondrial capacity during the full myogenic program of $\mathrm{C}_{2} \mathrm{C}_{12}$ myoblasts. We 
show that expression and activity levels of genes known for their regulatory role in skeletal muscle oxidative capabilities parallel the observed increase in oxidative parameters. Based on our results we propose that increased PGC- $1 \alpha$ expression, either directly or through increased PPAR- $\alpha$ expression levels and PPAR transcriptional activity, mediates mitochondrial biogenesis and concurrent up-regulation of skeletal muscle OXPHEN during myogenic differentiation.

\section{Funding}

The research of Dr. H. Gosker is supported by a grant from the Netherlands Asthma Foundation (NAF 3.4.05.038). The research of Dr. P. Schrauwen has been made possible by fellowships of the Royal Netherlands Academy of Arts and Sciences. Dr. Langen was sponsored by a VENI grant (VENI 916.56.112). A. Remels is supported by a grant from Numico Research.

\section{Disclosures}

Funding sources had no involvement in collection, analysis, and interpretation of data; in the writing of the report; and in the decision to submit the paper for publication. The authors would like to disclose that there are no advisory board affiliations or financial or personal interests in any organization sponsoring the research and accept full responsibility for conduct of the study and the decision to publish the present work. We declare that the manuscript, including related data, figures and tables, has not been previously reported or published, that the manuscript is not under consideration elsewhere, and that it will not be submitted elsewhere while under review by the journal of Molecular and Cellular Endocrinology.

\section{Acknowledgements}

The authors like to thank E. Phielix for excellent technical support in measurements of cellular respiration and M. Kelders for technical assistance in QPCR analysis.

\section{References}

Altman, D.G., Gore, S.M., Gardner, M.J., Pocock, S.J., 1983. Statistical guidelines for contributors to medical journals. Br. Med. J. (Clin. Res. Ed.) 286, 1489-1493.

Anderson, J.E., 2006. The satellite cell as a companion in skeletal muscle plasticity: currency, conveyance, clue, connector and colander. J. Exp. Biol. 209, 2276-2292.

Baar, K., 2004. Involvement of PPAR gamma co-activator-1, nuclear respiratory factors 1 and 2, and PPAR alpha in the adaptive response to endurance exercise. Proc. Nutr. Soc. 63, 269-273.

Baldwin, K.M., Haddad, F., 2002. Skeletal muscle plasticity: cellular and molecular responses to altered physical activity paradigms. Am. J. Phys. Med. Rehabil. 81, S40-S51.

Bedu, E., Desplanches, D., Pequignot, J., Bordier, B., Desvergne, B., 2007. Double gene deletion reveals the lack of cooperation between PPARalpha and PPARbeta in skeletal muscle. Biochem. Biophys. Res. Commun. 357, 877-881.

Butow, R.A., Bahassi, E.M., 1999. Adaptive thermogenesis: orchestrating mitochondrial biogenesis. Curr. Biol. 9, R767-R769.

Canto, C., Pich, S., Paz, J.C., Sanches, R., Martinez, V., Orpinell, M., Palacin, M., Zorzano, A., Guma, A., 2007. Neuregulins increase mitochondrial oxidative capacity and insulin sensitivity in skeletal muscle cells. Diabetes 56, 2185-2193.

Duguez, S., Feasson, L., Denis, C., Freyssenet, D., 2002. Mitochondrial biogenesis during skeletal muscle regeneration. Am. J. Physiol. Endocrinol. Metab. 282, E802-E809.

Duguez, S., Sabido, O., Freyssenet, D., 2004. Mitochondrial-dependent regulation of myoblast proliferation. Exp. Cell Res. 299, 27-35.

Fluck, M., 2006. Functional, structural and molecular plasticity of mammalian skeletal muscle in response to exercise stimuli. J. Exp. Biol. 209, 2239-2248.

Fredenrich, A., Grimaldi, P.A., 2004. Roles of peroxisome proliferator-activated receptor delta in skeletal muscle function and adaptation. Curr. Opin. Clin. Nutr. Metab. Care 7, 377-381.

Gleyzer, N., Vercauteren, K., Scarpulla, R.C., 2005. Control of mitochondrial transcription specificity factors (TFB1M and TFB2M) by nuclear respiratory factors (NRF-1 and NRF-2) and PGC-1 family coactivators. Mol. Cell Biol. 25, 1354-1366.

Gosker, H.R., Schrauwen, P., Broekhuizen, R., Hesselink, M.K., Moonen-Kornips, E., Ward, K.A., Franssen, F.F., Wouters, E.F., Schols, A.M., 2005. Exercise train- ing restores uncoupling protein-3 content in limb muscles of patients with chronic obstructive pulmonary disease. Am. J. Physiol. Endocrinol. Metab. 290, E976-E981.

Gosker, H.R., van Mameren, H., van Dijk, P.J., Engelen, M.P., van der Vusse, G.J., Wouters, E.F., Schols, A.M., 2002. Skeletal muscle fibre-type shifting and metabolic profile in patients with chronic obstructive pulmonary disease. Eur. Respir. J. 19, 617-625.

Herzberg, N.H., Zwart, R., Wolterman, R.A., Ruiter, J.P., Wanders, R.J., Bolhuis, P.A., van den Bogert, C., 1993. Differentiation and proliferation of respiration-deficient human myoblasts. Biochim. Biophys. Acta 1181, 63-67.

Hu, E., Tontonoz, P., Spiegelman, B.M., 1995. Transdifferentiation of myoblasts by the adipogenic transcription factors PPAR gamma and C/EBP alpha. Proc. Natl. Acad. Sci. U. S. A. 92, 9856-9860.

Ishii, K.A., Fumoto, T., Iwai, K., Takeshita, S., Ito, M., Shimohata, N., Aburatani, H., Taketani, S., Lelliott, C.J., Vidal-Puig, A., Ikeda, K., 2009. Coordination of PGC1 beta and iron uptake in mitochondrial biogenesis and osteoclast activation. Nat. Med. 15, 259-266.

Jahnke, V.E., Sabido, O., Freyssenet, D., 2009. Control of mitochondrial biogenesis, ROS level, and cytosolic $\mathrm{Ca}^{2+}$ concentration during the cell cycle and the onset of differentiation in L6E9 myoblasts. Am. J. Physiol. Cell Physiol. 296, C1185C1194.

Kim, K., Lecordier, A., Bowman, L.H., 1995. Both nuclear and mitochondrial cytochrome $c$ oxidase mRNA levels increase dramatically during mouse postnatal development. Biochem. J. 306 (Pt. 2), 353-358.

Kleiner, S., Nguyen-Tran, V., Bare, O., Huang, X., Spiegelman, B., Wu, Z., 2009. $\operatorname{PPAR}\{$ delta\} agonism activates fatty acid oxidation via PGC- 1 \{alpha\} but does not increase mitochondrial gene expression and function. J. Biol. Chem. 284, 18624-18633.

Koves, T.R., Li, P., An, J., Akimoto, T., Slentz, D., Ilkayeva, O., Dohm, G.L., Yan, Z., Newgard, C.B., Muoio, D.M., 2005. Peroxisome proliferator-activated receptor-gamma co-activator 1alpha-mediated metabolic remodeling of skeletal myocytes mimics exercise training and reverses lipid-induced mitochondrial inefficiency. J. Biol. Chem. 280, 33588-33598.

Kraft, C.S., LeMoine, C.M., Lyons, C.N., Michaud, D., Mueller, C.R., Moyes, C.D., 2006. Control of mitochondrial biogenesis during myogenesis. Am. J. Physiol. Cell Physiol. 290, C1119-C1127.

Langen, R.C., Schols, A.M., Kelders, M.C., Wouters, E.F., Janssen-Heininger, Y.M., 2003. Enhanced myogenic differentiation by extracellular matrix is regulated at the early stages of myogenesis. In Vitro Cell Dev. Biol. Anim. 39, 163-169.

Le Grand, F., Rudnicki, M.A., 2007. Skeletal muscle satellite cells and adult myogenesis. Curr. Opin. Cell Biol. 19, 628-633.

Leary, S.C., Battersby, B.J., Hansford, R.G., Moyes, C.D., 1998. Interactions between bioenergetics and mitochondrial biogenesis. Biochim. Biophys. Acta 1365, 522-530.

Lefebvre, P., Chinetti, G., Fruchart, J.C., Staels, B., 2006. Sorting out the roles of PPAR alpha in energy metabolism and vascular homeostasis. J. Clin. Invest. 116, 571-580.

Leick, L., Hellsten, Y., Fentz, J., Lyngby, S.S., Wojtaszewski, J.F., Hidalgo, J., Pilegaard, H., 2009. PGC-1 \{alpha\} mediates exercise-induced skeletal muscle VEGF expression in mice. Am. J. Physiol. Endocrinol. Metab. 297, E92-E103.

Leick, L., Wojtaszewski, J.F., Johansen, S.T., Kiilerich, K., Comes, G., Hellsten, Y., Hidalgo, J., Pilegaard, H., 2008. PGC-1alpha is not mandatory for exercise- and training-induced adaptive gene responses in mouse skeletal muscle. Am. J. Physiol. Endocrinol. Metab. 294, E463-E474.

Lin, J., Wu, H., Tarr, P.T., Zhang, C.Y., Wu, Z., Boss, O., Michael, L.F., Puigserver, P., Isotani, E., Olson, E.N., Lowell, B.B., Bassel-Duby, R., Spiegelman, B.M., 2002. Transcriptional co-activator PGC-1 alpha drives the formation of slow-twitch muscle fibres. Nature 418, 797-801.

Lin, J., Wu, P.H., Tarr, P.T., Lindenberg, K.S., St-Pierre, J., Zhang, C.Y., Mootha, V.K., Jager, S., Vianna, C.R., Reznick, R.M., Cui, L., Manieri, M., Donovan, M.X., Wu, Z Cooper, M.P., Fan, M.C., Rohas, L.M., Zavacki, A.M., Cinti, S., Shulman, G.I., Lowell, B.B., Krainc, D., Spiegelman, B.M., 2004. Defects in adaptive energy metabolism with CNS-linked hyperactivity in PGC-1alpha null mice. Cell 119, 121135.

Luquet, S., Gaudel, C., Holst, D., Lopez-Soriano, J., Jehl-Pietri, C., Fredenrich, A., Grimaldi, P.A., 2005. Roles of PPAR delta in lipid absorption and metabolism: a new target for the treatment of type 2 diabetes. Biochim. Biophys. Acta 1740, 313-317.

Luquet, S., Lopez-Soriano, J., Holst, D., Fredenrich, A., Melki, J., Rassoulzadegan, M., Grimaldi, P.A., 2003. Peroxisome proliferator-activated receptor delta controls muscle development and oxidative capability. FASEB J. 17, 2299-2301.

Mathieu-Costello, O., Hepple, R.T., 2002. Muscle structural capacity for oxygen flux from capillary to fiber mitochondria. Exerc. Sport Sci. Rev. 30, 80-84.

Moyes, C.D., Mathieu-Costello, O.A., Tsuchiya, N., Filburn, C., Hansford, R.G., 1997. Mitochondrial biogenesis during cellular differentiation. Am. J. Physiol. 272, C1345-C1351.

Narici, M.V., Reeves, N.D., Morse, C.I., Maganaris, C.N., 2004. Muscular adaptations to resistance exercise in the elderly. J. Musculoskelet. Neuronal Interact. 4, $161-164$.

Oexle, K., Kohlschutter, A., 2001. Cause of progression in Duchenne muscular dystrophy: impaired differentiation more probable than replicative aging. Neuropediatrics 32, 123-129.

Rochard, P., Rodier, A., Casas, F., Cassar-Malek, I., Marchal-Victorion, S., Daury, L., Wrutniak, C., Cabello, G., 2000. Mitochondrial activity is involved in the regulation of myoblast differentiation through myogenin expression and activity of myogenic factors. J. Biol. Chem. 275, 2733-2744. 
Scarpulla, R.C., 2008. Nuclear control of respiratory chain expression by nuclear respiratory factors and PGC-1-related coactivator. Ann. N. Y. Acad. Sci. 1147, 321-334.

Scarpulla, R.C., 2002. Transcriptional activators and coactivators in the nuclear control of mitochondrial function in mammalian cells. Gene 286, 81-89.

Seyer, P., Grandemange, S., Busson, M., Carazo, A., Gamaleri, F., Pessemesse, L., Casas, F., Cabello, G., Wrutniak-Cabello, C., 2006. Mitochondrial activity regulates myoblast differentiation by control of c-Myc expression. J. Cell Physiol. 207, 75-86.

Singh, J., Verma, N.K., Kansagra, S.M., Kate, B.N., Dey, C.S., 2007. Altered PPARgamma expression inhibits myogenic differentiation in $\mathrm{C}_{2} \mathrm{C}_{12}$ skeletal muscle cells. Mol. Cell. Biochem. 294, 163-171.

Vandesompele, J., De Preter, K., Pattyn, F., Poppe, B., Van Roy, N., De Paepe, A., Speleman, F., 2002. Accurate normalization of real-time quantitative RT-PCR data by geometric averaging of multiple internal control genes. Genome Biol. 3, RESEARCH0034.
Wallace, G.Q., McNally, E.M., 2009. Mechanisms of muscle degeneration, regeneration, and repair in the muscular dystrophies. Annu. Rev. Physiol. 71, 3757.

Wang, Y.X., Lee, C.H., Tiep, S., Yu, R.T., Ham, J., Kang, H., Evans, R.M., 2003. Peroxisome-proliferator-activated receptor delta activates fat metabolism to prevent obesity. Cell 113, 159-170.

Wang, Y.X., Zhang, C.L., Yu, R.T., Cho, H.K., Nelson, M.C., Bayuga-Ocampo, C.R., Ham, J., Kang, H., Evans, R.M., 2004. Regulation of muscle fiber type and running endurance by PPARdelta. PLoS Biol. 2, e294.

Wu, Z., Puigserver, P., Andersson, U., Zhang, C., Adelmant, G., Mootha, V., Troy, A., Cinti, S., Lowell, B., Scarpulla, R.C., Spiegelman, B.M., 1999. Mechanisms controlling mitochondrial biogenesis and respiration through the thermogenic coactivator PGC-1. Cell 98, 115-124.

Yaffe, D., Saxel, O., 1977. Serial passaging and differentiation of myogenic cells isolated from dystrophic mouse muscle. Nature 270, 725-727. 